\title{
The role of educational motivation in the creativity of intellectually gifted primary schoolchildren
}

\author{
Natalia B. Shumakova ${ }^{1 *}$ \\ ${ }^{1}$ Psychological Institute of the Russian Academy of Education, Psychology of Giftedness Department, \\ Moscow, Russia
}

\begin{abstract}
The importance of external and internal motivation in the academic success of students and their persistence in achieving educational and cognitive goals is considered within the framework of the theory of self-determination. The role of different types of educational motivation in the development of the creative potential of students remains insufficiently studied, especially in relation to primary schoolchildren. The research objective is to clarify the role of different motives for learning activity through differences in the figurative and verbal creativity of intellectually gifted primary schoolchildren on the threshold of adolescence. The study involved 96 intellectually gifted primary schoolchildren of the $3^{\text {rd }}-4^{\text {th }}$ grades (the average age is 9.6; the number of boys and girls is the same). The internal and external motivation of their educational activity was studied using the "Scale of educational motivation" developed by T.O. Gordeeva based on the Academic Self-Regulation Questionnaire (SRQ-A) by Ryan and Connell. Divergent creativity was analyzed using N.B. Shumakova's methodology "Figurative and verbal creativity". An ambiguous relationship has been revealed between different types of motivation and indicators of verbal and imaginative creativity. Internal cognitive motivation and self-development are reliably and directly related to imaginative fluency $(\mathrm{r}=0.28$ and $\mathrm{r}=0.24)$, while external motivation (parental regulation) and imaginative creativity (including imaginative originality and elaboration) are linked reversely $(\mathrm{r}=-0.31, \mathrm{r}=-0.24)$. The regression analysis has demonstrated that external motivation (learning for the sake of fulfilling the parents' requirements) at primary school age is a negative predictor of imaginative creativity and originality of intellectually gifted students in their adolescence $(\mathrm{F}=6.91, \beta=-0.321, \mathrm{p}=0.01$ and $\mathrm{F}=6.57$, $\beta=-0.314, p=0.01$ ).
\end{abstract}

Keywords: external and internal motivation, intellectual giftedness, creativity, primary schoolchildren.

\footnotetext{
*Corresponding author: n_shumakova@mail.ru
} 


\section{Introduction}

The great attention of scholars from different countries to the educational and cognitive motivation of schoolchildren and students is conditioned by its exceptional role in educational activities and academic success. Numerous studies conducted within the framework of the theory of self-determination developed by E. Desi and R. Ryan have emphasized the importance of different types of internal and external educational motivation in the academic success of students and their persistence in achieving educational and cognitive goals [1-5]. In addition, research in the field of giftedness has proved the exceptional role of motivational-personal and psycho-social variables in the development of talent and outstanding achievement [6-11]. However, fewer empirical studies reveal the role of different types of educational motivation in the development and implementation of the creative potential of schoolchildren. Since developing creativity is one of the main tasks of modern school education and motivation can become an obstacle to the "spread of creativity" [9: 167], the study of motivational factors and predictors of schoolchildren's creativity (especially those on the verge of adolescence) acquires special relevance. It is also unclear how the specifics of motivational profiles condition differences in the creativity of intellectually gifted primary school children and adolescents. The research objective is to clarify the role of different motives for learning activity through differences in the figurative and verbal creativity of intellectually gifted primary schoolchildren on the threshold of adolescence.

The main hypothesis of the study is that intellectually gifted younger adolescents demonstrating high levels of educational and cognitive motives (internal motivation) also show higher indicators of creativity than their intellectually gifted peers with a high level of external motivation.

\section{Methods}

Sampling. The study involved 96 intellectually gifted primary schoolchildren of the $3^{\text {rd }}-4^{\text {th }}$ grades at the age of 9-10 years (the average age was 9.6) studying at a Moscow school (the number of boys and girls was equal). Consequently, their creativity was retested after 12 months.

To study the internal and external motivation of the educational activity of schoolchildren, we used the "Scale of educational motivation" developed by T.O. Gordeeva based on the Academic Self-Regulation Questionnaire (SRQ-A) introduced by Ryan and Connel [12]. The questionnaire consists of 36 statements representing seven scales: internal cognitive motivation and self-development motivation, identified regulation, positive and negative introjected regulation, external regulation (teachers and parents).

To consider divergent creativity as the ability to produce various and original ideas (verbal creativity) and create new graphic images (figurative creativity), we used the method called "Figurative and verbal creativity" [13]. This methodology allows recording such cognitive indicators as fluency, flexibility, originality and elaboration in the verbal and graphic sphere.

\section{Results}

While analyzing the results obtained, we have calculated average values for educational motivation scales and creativity indicators, as well as the rank correlation coefficients of various types of motivation with indicators of verbal and imaginative creativity. All the average values on the scales of internal educational motivation were high. In relation to 
external motivation, they turned to be moderate for positive introjected regulation (selfesteem motivation), negative (feelings of guilt and shame) for external teachers' regulation and high for external parental regulation ("I try to study well and solve complex tasks for my parents. They either praise me or lecture"). In general, the average value of the total indicator of internal motivation exceeds that of external motivation, which is consistent with the existing data on the domination of internal motivation over external one in gifted children. Table 1 demonstrates the correlations between educational motivation scales and indicators of verbal and non-verbal creativity.

Table 1. Intercorrelations of educational motivation scales and indicators of verbal and non-verbal creativity.

\begin{tabular}{|c|c|c|c|c|c|c|}
\hline & \multicolumn{6}{|c|}{ Educational motivation scales } \\
\hline & Cognition & $\begin{array}{c}\text { Self- } \\
\text { development }\end{array}$ & $\begin{array}{c}\text { Introjected } \\
\text { (positive) }\end{array}$ & $\begin{array}{c}\text { External: } \\
\text { teachers }\end{array}$ & $\begin{array}{c}\text { External: } \\
\text { parents }\end{array}$ & $\begin{array}{c}\text { External } \\
\text { (general) }\end{array}$ \\
\hline $\begin{array}{c}\text { Verbal } \\
\text { fluency }\end{array}$ & 0.139 & 0.136 & -0.149 & -0.153 & -0.156 & 0.035 \\
\hline $\begin{array}{c}\text { Verbal } \\
\text { flexibility }\end{array}$ & 0.113 & 0.058 & -0.165 & -0.169 & -0.106 & -0.073 \\
\hline $\begin{array}{c}\text { Verbal } \\
\text { originality }\end{array}$ & 0.195 & 0.167 & -0.062 & -0.127 & -0.068 & -0.004 \\
\hline $\begin{array}{c}\text { Verbal } \\
\text { creativity } \\
\text { (general) }\end{array}$ & 0.152 & 0.136 & -0.119 & -0.149 & -0.127 & -0.018 \\
\hline $\begin{array}{c}\text { Imaginative } \\
\text { fluency }\end{array}$ & $0.280^{*}$ & $0.242^{*}$ & 0.105 & -0.082 & -0.192 & -0.100 \\
\hline $\begin{array}{c}\text { Imaginative } \\
\text { flexibility }\end{array}$ & 0.183 & 0.115 & -0.059 & -0.069 & -0.114 & -0.073 \\
\hline $\begin{array}{c}\text { Imaginative } \\
\text { originality }\end{array}$ & 0.125 & 0.131 & -0.166 & -0.183 & $-0.306^{* *}$ & -0.129 \\
\hline $\begin{array}{c}\text { Imaginative } \\
\text { elaboration }\end{array}$ & 0.069 & 0.044 & $0.649 * * *$ & 0.020 & $-0.235^{*}$ & -0.079 \\
\hline $\begin{array}{c}\text { Imaginative } \\
\text { creativity } \\
\text { (general) }\end{array}$ & 0.201 & 0.169 & -0.161 & -0.125 & $-0.280^{*}$ & -0.149 \\
\hline
\end{tabular}

Note: Significant level of correlations: ${ }^{*}-\mathrm{p} \leq 0.05 ;{ }^{* *}-\mathrm{p} \leq 0.01 ; * * *-\mathrm{p} \leq 0.001$.

The table above shows that none of the types of internal and external motivation has a reliable connection with verbal creativity and its features in intellectually gifted primary schoolchildren. However, it is not the case with imaginative creativity. Two types of internal motivation (cognitive and self-development) have a direct relationship with the figurative (drawing) fluency of intellectually gifted primary schoolchildren. On the contrary, external motivation (parental regulation) has an inverse relationship with imaginative originality and development. Interestingly, there is a statistically significant connection between self-esteem motivation and elaboration, which is manifested in the ability of primary school children to develop (elaborate) their ideas presented in the form of drawings.

Finally, we performed multiple regression analyses to identify motivational predictors of the figurative and verbal creativity of intellectually gifted primary schoolchildren on the threshold of adolescence. We considered different indicators of educational motivation as independent variables. Dependent variables were indicators of the figurative and verbal creativity of students retested after 12 months. As a result, we have not found any significant positive or negative predictors of verbal creativity. At the same time, a 
significant negative predictor of imaginative creativity and originality is the external regulation of learning (by parents) $(\mathrm{F}=6.91, \beta=-0.321, \mathrm{p}=0.01$ and $\mathrm{F}=6.57, \beta=-0.314$, $\mathrm{p}=0.01$, respectively).

\section{Discussion}

The descriptive statistics of the motivational characteristics of intellectually gifted primary schoolchildren has confirmed the existing data on gifted children with internal educational motivation prevailing over external one $[11 ; 14]$. Among external motives for learning, parental regulation dominates (learning for the sake of fulfilling the requirements of parents), which is significantly manifested in intellectually gifted primary schoolchildren. A clear orientation towards parental approval can be the reverse side of an especially close (sometimes almost symbiotic) relationship between gifted children and their mothers, or the father's authoritarian parenting style described in the relevant literature [15: 121].

The internal and external motives of educational activity play different roles in the verbal and imaginative creativity of intellectually gifted primary schoolchildren. Internal cognitive motivation and self-development, as we assumed, are weakly but positively associated with figurative fluency. There are no such connections in relation to the indicators of verbal creativity. The assumption about a negative relationship between external motivation and creativity has been partially confirmed. This connection is true only for external parental regulation and imaginative creativity (as well as originality and elaboration). At the same time, the role of external regulation is ambiguous. For example, self-esteem motivation is positively associated with drawing skills in contrast to parental regulation.

High external motivation (learning for the sake of fulfilling the requirements of parents) in intellectually gifted primary school children is a negative predictor of imaginative creativity and originality. Thus, excessive pressure and parental care can lead to the wellknown phenomenon of "high intelligence and low creativity" among intellectually gifted adolescents.

\section{Conclusion}

This study shows a significant and ambiguous role of educational motivation in the creativity of intellectually gifted primary schoolchildren on the threshold of adolescence. This allows a deeper understanding of individual differences in verbal and figurative divergent creativity and the consequences of different motivation types presented in such children.

However, the article lacks gender analysis, which should be conducted in further study.

\section{References}

1. T.O. Gordeeva, O.A. Sychev, V.V. Gizhitskii, T.K. Gavrichenkova, Psikhologicheskaya Nauka i Obrazovanie, 2, 65-74 (2017). https://doi.org/10.17759/pse.2017220206

2. W.S. Grolnick, R.M. Ryan, E.L. Deci, Journal of Educational Psychology, 83(4), 508517 (1991). https://doi.org/10.1037/0022-0663.83.4.508

3. R.M. Ryan, E.L. Deci, Self-determination theory: Basic psychological needs in motivation, development, and wellness (Guilford Publications, New York, 2017) 
4. G. Taylor, T. Jungert, G.A. Mageau, Contemporary Educational Psychology, 39(4), 342-358 (2014). https://doi.org/10.1016/j.cedpsych.2014.08.002

5. M. Vansteenkiste, E. Sierens, B. Soenens, Journal of Educational Psychology, 101(3), 671-688 (2009). https://doi.org/10.1037/a0015083

6. L.I. Larionova, Vzaimosvyaz koeffitsienta intellekta s lichnostnymi kharakteristikami odarennykh shkolnikov [The relationship between the mental ratio and personality traits of gifted schoolchildren], in Rebenok v obrazovatelnom prostranstve megapolisa: Proceedings of the $2^{\text {nd }}$ Transregional scientific conference, 66-70, MGPU, Moscow, (2015)

7. N.V. Meshkova, Sovremennaya Zarubezhnaya Psikhologiya, 4(1), 26-44 (2015). Accessed on: January 10, 2020. [Online]. Available: http://psyjournals.ru/jmfp/2015/n1/76175.shtml

8. A.I. Savenkov, Zhurnal Vysshei Shkoly Ekonomiki, 2(4), 94-101 (2005)

9. A.S. Sukhorukov, E.N. Lunina, Motivatsionnye osnovy kreativnosti [The motivational foundations of creativity], in Tvorchestvo v sovremennom mire: chelovek, obshchestvo, tekhnologii, Proceedings of the All-Russian scientific conference dedicated to the $100^{\text {th }}$ anniversary of Ya.A. Ponomarev, the Institute of Psychology of the Russian Academy of Sciences, September 26-27, 2020, Moscow, Institut psikhologii RAN, 167-168 (2020)

10. E.I. Shcheblanova, Teoreticheskaya i eksperimentalnaya psikhologiya, 11(4), 39-53 (2018). Accessed on: November 23, 2020. [Online]. Available: https://elibrary.ru/item.asp?id=38235436

11. R. Subotnik, P. Olszewski-Kubilius, F. Worrell, Psychological Science in the Public Interest, 12(1), 3-54 (2011). https://doi.org/10.1177/1529100611418056

12. T.O. Gordeeva, O.A. Sychev, M.F. Lynch, Psychology in Russia: State of the Art, 13(3), 16-34 (2020). https://doi.org/10.11621/ pir.2020.0301

13. N.B. Shumakova, Psikhologo-pedagogicheskie Issledovaniya, 9(4), 108-117 (2017). https://doi.org/10.17759/psyedu.2017090411

14. T.O. Gordeeva, O.A. Sychev, Vestnik Moskovskogo Universiteta, Seriya 14, Psikhologiya, 1, 67-87 (2017). https://doi.org/10.11621/vsp.2017.01.69

15. V.S. Yurkevich, Psikhologicheskaya Nauka i Obrazovanie, 2(5) (2020). Accessed on: November 23, 2020. [Online]. Available:

https://psyjournals.ru/psyedu_ru/2010/n5/Yurkevich.shtml 